Fighting for Indigenous Lands in Modern Brazil.

The reframing of cultures and identities

\title{
The return of relatives:
}

\section{processes of mobilisation and village construction among the Tupinambá of Serra do Padeiro, southern Bahia, Brazil}

\author{
Daniela Fernandes Alarcon' \\ 'Programa de Pós-Graduação em Antropologia Social, Museu Nacional, \\ Universidade Federal do Rio de Janeiro, Rio de Janeiro/RJ, Brasil
}

\begin{abstract}
The article examines land reclamations, actions of territorial recovery engaged in by the Tupinambá of the village of Serra do Padeiro, in southern Bahia, Brazil. It focuses on the return of relatives - i.e. the return of expropriated Indians as part of the reclamation process -, and seeks to examine the construction of the collective political subject that has engendered the reclamations, as it is engendered by them. The text presents a brief history of the process of territorialisation, indicating how the reclamations have become the group's main form of political action. I argue that the process of land recovery is based on kinship, and is capable of activating latent ties or lead to the weakening or rupture of ties between relatives in opposing positions. I also propose that the reclamation process has extended the meaning of relative, providing nuance to the emphasis on blood and moving towards a definition of relative as those with whom you fight together.
\end{abstract}

Keywords: indigenous peoples; Tupinambá; land reclamations; mobilisation. 


\section{O retorno dos parentes:}

\section{processos de mobilização e construção da aldeia entre}

\section{os Tupinambá da Serra do Padeiro, sul da Bahia, Brasil}

\section{Resumo}

O artigo debruça-se sobre as retomadas de terras, ações de recuperação territorial realizadas pelos Tupinambá da aldeia Serra do Padeiro, sul da Bahia, Brasil. Focaliza o retorno dos parentes - isto é, o retorno, no marco do processo de retomada, de indígenas expropriados. Busca-se examinar a construção do sujeito político coletivo que vem engendrando as retomadas, ao tempo em que é por elas engendrado. $O$ texto apresenta um breve histórico do processo de territorialização, indicando como as retomadas vieram a constituir a principal forma de ação política do grupo. Argumenta-se que o processo de retomada assenta-se no parentesco, sendo capaz de ativar vínculos latentes ou levar ao enfraquecimento ou ao rompimento de laços entre parentes em posições opostas. Propõe-se, ainda, que o processo de retomada teria alargado o significado de parente, matizando a ênfase no sangue e avançando para a definição de parente como aquele com quem se luta junto.

Palavras-chave: povos indígenas; Tupinambá; retomadas de terras; mobilização. 


\title{
The return of relatives:
}

\section{processes of mobilisation and village construction among the Tupinambá of Serra do Padeiro, southern Bahia, Brazil}

\author{
Daniela Fernandes Alarcon
}

Since 2004, the Tupinambá of the village of Serra do Padeiro, situated in Tupinambá de Olivença Indigenous Territory (located in the southern part of the State of Bahia, in the Brazilian Northeast), have been engaged in land reclamations. The reclamations can be defined succinctly as actions by this people to recover areas traditionally occupied by them that were in the possession of non-Indians ${ }^{1}$. Swallowed up by the advance of the frontier in southern Bahia, particularly from the end of the nineteenth century, these lands extend back to the ancestors that appear in the origin of the familial lineages that currently make up the village. These are lands with history. They are also lands with owners: they belong to the encantados, nonhuman entities central to the Tupinambá cosmology. As I conclude this text, the Tupinambá of Serra do Padeiro possess 89 former farms, now reclaimed, in addition to the smallholdings they have managed to maintain over time, despite expropriation ${ }^{2}$. Although they have significantly expanded the size of the area they occupy, it remains discontinuous, since areas in the possession of non-Indians persist within their territory.

As several authors have highlighted, over the last few decades, peasant movements have established "a certain 'style' of mobilisation and manifestation, crystallising a well-defined repertoire of collective action with public visibility, recurrently activated" (Comerford 1999: 125). In the Brazilian Northeast, the generalisation of land reclamation as a form of political action has turned it into the virtual epitome of indigenous mobilisation. However, although the reclamations are widespread and well known, studies on them are curiously scarce ${ }^{3}$. Considering their centrality to the social organisation of the Tupinambá of Serra do Padeiro - the reclamations can be understood as constitutive of the village in its contemporary formation -, to me it seems essential to examine them closely, describing and analysing their antecedents, recurrent characteristics and their repercussions on the framework of relationships in which the indigenous people are inscribed.

\footnotetext{
1 As Alfredo Wagner Berno de Almeida emphasises, the advance of the capitalist frontier is incapable of undermining "specific territorialities", based on different modes of appropriation and common land use, which present "more definitive or contingent delimitations depending on the correlation of force in each social situation of antagonism" (Almeida 2008: 51).

2 In a survey completed in July 2016, I managed to identify 89 reclaimed farms in the village of Serra do Padeiro. By comparing data from distinct sources, mainly provided by the Indians and obtained in possessory actions, I gathered information regarding the areas (name of the farm, georeferenced location, area in hectares, alleged owner, date of reclamation action, current residents, and legal situation, among others). At the time, through a non-exhaustive survey, I was able to obtain more or less detailed information about 40 smallholdings in possession of the Serra do Padeiro Indians (name of the smallholding, georeferenced location, area in hectares, family lineage to which the area refers, situation of land ownership, history of possible attempts of expropriation and current residents, among others). The meanings of farm and smallholding invoked in this text require further explanation. Farm does not simply designate an area of land, but rather a historically constituted entity, within a framework of asymmetric relationships of power; in some ways, it is the materialisation of the process of penetration by non-Indians in indigenous territory. Smallholding, in turn, can be understood according to the meanings proposed by Woortmann (1994) ("kinship territory", land that is inherited) and Woortmann (1988) ("territory of reciprocity"). In general, they are smallholdings maintained by the Indians over numerous generations, constituting the territorial substratum of nuclear or extended families.

3 See Tófoli (2010), who focused on the Tapeba case, in Ceará, also in the Brazilian Northeast; Benites (2014), who investigated reclamations among the Guarani and Kaiowa, in Mato Grosso do Sul, in the Midwest; and Faria (2016), who investigated reclamations engaged in by the Guarani Mbyá of São Paulo, in the Southeast. And, as indicated, Alarcon (2013), on the Tupinambá of Serra do Padeiro. See also Pacheco de Oliveira et al. (2015).
} 
When referring to the process of territorial recovery, the Tupinamba of Serra do Padeiro often use the category return of the land (Alarcon 2013). As you can see, it is the land that returns - as the Indians liberate portions that had been trapped in farms, the integrity of the mutilated territory is restored. This return unfolds in circumscribed but connected returns: the return of the encantados, also impacted by the despoliation; the return of the animals; and the return of relatives. Mobilising dispersed relatives to engage in the struggle and creating everyday forms of living together, the Tupinambá have been defining a collective project for village construction, in which land is not depicted as a tradable property, but as a precondition for living well.

In this context, rather than the mere recovery of areas of land, a broad process of memory recovery is triggered, since reclamation actions make the land speak, that is, these actions put into circulation stories related to those specific portions of the territory and to the ancestors who lived there, projecting these words into the future. As indicated by Pollak (1989), it is a movement through which underground memories emerge, producing a latent threat to the framework operated by the dominators. Even the proposition of possessory actions with the intention of halting or reversing the reclamation process, while enacting violence against the Indians, has the unintentional effect of publicising the multiple forms of violence that underlie the constitution of private property in indigenous territory, making documents that materialise the same accessible.

It is important to emphasise that the reclamation process is closely linked to State recognition of the territorial rights of the Tupinambá, even though it extends beyond it, as I hope to indicate. The administrative procedure of demarcation (official recognition) of the Tupinambá de Olivença Indigenous Territory - which covers approximately 47,00o hectares, comprising portions of the municipalities of Buerarema, Ilhéus and Una - also began in $2004^{4}$ in response to the Tupinambá mobilisation, which had become more visible since the 199 os $^{5}$. At all stages, the process has been characterised by the violation of legal deadlines, which motivated the Brazilian Federal Prosecution Service to propose actions that hold the Brazilian State responsible for noncompliance with its legal obligations ${ }^{6}$. In an attempt to halt the progress of the procedure, individuals and groups mobilised against demarcation have pressured the federal government and turned to the judiciary. In 2016, the demarcation process was suspended for five months as a result of a preventive injunction filed three years earlier. Upon conclusion of this article, the demarcation procedure had been paralysed for five years, without justification, pending the referral of the Minister of Justice?

Historically united by kinship ties and the sharing of a common ethnic identity, the Tupinambá are distributed over numerous localities, including Serra do Padeiro. Covered by the Atlantic Forest and associated ecosystems, the indigenous territory extends east to west from the coast to the mountainous

\footnotetext{
4 Here I adopt the establishment of the working group in charge of the identification and delimitation studies of the Indigenous Territory as the point of initiation of the demarcation procedure. The working group was established by the presidency of the National Indian Foundation (FUNAI) by means of ordinance 102, dated January 22nd, 2004 (attached document to Brazil, Ministry of Justice, FUNAI 2009). It is worth noting that the Tupinambá people were officially recognised by the Brazilian State on May 13th, 2002 (Technical note no. 01/02/General Coordination of Studies and Research of the National Indian Foundation, annexed to Brazil, Ministry of Justice, National Indian Foundation 2009). At the time, the country had not yet adopted the International Labour Organisation (ILO) Convention 169, which determines self-identification as a criterion for the recognition of indigenous groups.

5 For a sociogenesis of the Tupinambá movement, see Magalhães (2010), Couto (2003, 2008) and Viegas (2007). For strategies conducted by the Indians in the extremely unfavourable context that extended from the late 1930s to the 1990s, see Alarcon (2013).

6 Although the demarcation procedure began in 2004, the Circumstantial Identification and Delimitation Report (RCID) for the Indigenous Territory was only published in the Federal Official Gazette on April $17^{\text {th }}, 2009$, in clear violation of Decree no. 1,775/1996, which regulates the process of recognition of indigenous territories. After rejecting all challenges to the demarcation, on March $2^{\text {nd }}$, 2012, FUNAI forwarded the case to the Ministry of Justice. On April $5^{\text {th }}$ of the same year, the legal consultation body of the ministry approved the studies elaborated by the FUNAI. However, neither the minister at the time nor those who have subsequently ascended to the office have taken further steps. Regarding the public civil actions proposed by the Federal Prosecution Service, see: Brazil, Federal Prosecution Service, Federal Public Prosecutor's Office, Ilhéus (2007, 2013) and Brazil, Federal Prosecution Service, Federal Public Prosecutor's Office, Bahia (2012).

7 For further information on the most recent developments in the process of demarcation, including its judicialisation, see Alarcon (2017).
} 
chain composed of the Trempes, Serrote and Padeiro serras and, north to south, from the Cururupe River to Mabaço Lagoon. There is no accurate data on the number of indigenous inhabitants of the indigenous territory, though considering official information, it is possible to estimate a population of about 5,000 people. In 2016, I counted slightly more than 480 Indians inhabiting the Serra do Padeiro, although the total number of village members was significantly higher, and encompassed Indians who were circumstantially not there, as I will detail below'.

Prior to the onset of the reclamation process, the Indians lived on farms (as sharecroppers or wage labourers, or maintaining other relationships with the alleged owners of these areas $^{10}$ ), in smallholdings, in towns in the region or in cities in the South and Southeast of the country, to which they had moved. The long process of territorialisation of the indigenous population of the region is marked by the establishment of the Jesuit village of Nossa Senhora da Escada in 1680, which today corresponds to Olivença, in the municipality of Ilhéus. As I shall discuss later, over time, areas in the possession of the Indians were drastically reduced, as large portions of the territory were devoted to farms. In the twentieth century, capitalist expansion on these lands intensified - driven by cocoa cultivation and tourism.

The process of territorial recovery engaged in by the Tupinambá of Serra do Padeiro has been the object of my academic investigations since 2010. Mobilising ethnographic and documentary data of different natures, I focus on land reclamations, which I understand as a specific expression among the modalities of political intervention (Pacheco de Oliveira 2006) contemporaneously constructed by indigenous peoples. This research forms part of a series of studies of interethnic relationships in Brazil, particularly in the Northeast, which is expressed in a growing number of academic works developed with indigenous peoples in the region, some of which have been presented in compilations, such as Pacheco de Oliveira (2004, 2011), Carvalho et al. (2011) and Carvalho \& Carvalho (2012).

The research I have been developing aims to describe and analyse the Tupinambá mobilisation in its dual meaning: the involvement of relatives in the reclamation process and the daily maintenance of engagement in a collective project. It is, therefore, a study framed in a field that recognises Indians as historical subjects whose actuation is often elided by hegemonic historiographical currents (Monteiro 2001, Pacheco de Oliveira 2016) and that seeks to shed light on collective projects that, because they clash with hegemonic projects, have been historically blocked and are being updated contemporaneously, within the contexts of territorial recovery.

In this article, focusing on the return of relatives, I seek to examine the process of construction of the collective political subject that has been engendering the land reclamations, which is simultaneously, continuously and reciprocally, engendered by them. Here, it is fundamental to recover the idea of the return journey, as elaborated by Pacheco de Oliveira (1998), particularly with regard to the relationship between ethnicity and territory. The author draws attention to "a powerful connection between the sense of belonging and a specific place of origin, where the individual and their magical components unite and identify with the land itself, becoming part of a common destiny" (Ibid: 64-65). In this sense, the territory

8 The Indigenous Health Care Information System of the Special Secretariat of Indigenous Health of the Ministry of Health (SIASI/SESAI/MS) registers 4,534 Indians in the Tupinambá de Olivença Indigenous Territory, for 2013. The 2010 Census counted 5,851 Tupinambá; it should be noted, however, that this number refers to all those who self-declared as Tupinambá, and the Brazilian Institute of Geography and Statistics (IBGE) does not provide disaggregated data for the indigenous territory in question (Brasil, Instituto Brasileiro de Geografia e Estatística 2012).

9 This data comes from a census I conducted in the village, and completed in July 2016. Of the 482 residents, 320 lived in reclaimed areas and 162 in smallholdings. I return to this question in due course.

10 The categories of farm work that were most frequently mentioned to me in Serra do Padeiro were: 1, working na meia or na ameia [as sharecroppers], i.e. according to an agricultural "partnership" contract, whether formalised or not, in which the Indians planted and/or tended to perennial crops, or planted short cycle crops, and divided production with the alleged owners of the areas according to variable percentages; 2, acting as a registered employee, i.e. with a formal contract; or 3, working na diária [day contract] or na empreita (also referred to as empreitada) [piece work], as a precarious labourer hired for eventual tasks and receiving payment for the day worked, in the first case, or per completed task, in the second. In their relationship with non-Indians, the Indians also experienced other agreements, mentioned less frequently. Regarding these work modalities, see also Caldeira (1954: 36-41) and Santos (1957: 109-110). 
mediates the relationship between the person and ethnic group, in a way that creates the conditions for the actuation of ethnicity. "Inscribed in their own body and always present [...], the relationship with the collectivity of origin refers to the domain of fatality, of the irrevocable, which establishes the north and the parameters of a concrete social trajectory" (Ibid: 65).

In the following section, I outline a brief history of the process of territorialisation of the Tupinambá, considering the mechanisms of territorial expropriation used against the Indians and the process by which the land reclamations became the group's main form of political action. I seek to provide elements that show that the political intervention engaged in by the Tupinambá is a dynamic process, a project that is not conflict-free, constructed within daily living and the framework of struggle - and which, therefore, cannot be satisfactorily grasped by crystallising descriptions that do not take into account its historicity. In the section after that, I narrow the focus to the process of mobilisation, arguing that we are facing a form of action based on kinship, the implementation of which is capable of activating bonds that were latent or, in contrast, lead to weakening or even the rupture of ties between relatives who maintain opposing positions. I further argue that the process of territorial recovery seems to have extended the meaning of relative.

\section{From caxixes and massacres to land reclamation}

Sitting in the kitchen at the foot of the mountain where she gave birth to ten children, Ms. Maria da Glória de Jesus extends her eyes to the yard, dominated by children running around during a break between classes. "Land is for living well", she says, in a deep voice, projecting her body. At the back of the house, large stones maintain the memory of the ambushes she and her husband had to face so as not to lose the place left to them by the elders. In more recent times, after the struggle for the demarcation of indigenous land began, five of Maria's children and a grandson had been imprisoned. On her left breast she bears the mark of a rubber bullet, which she got during police action to repossess land in 2008 , tellingly named by the State apparatus of repression as Operação Terra Firme [lit. Operation Solid Ground]"

The penetration of non-Indians on lands traditionally inhabited by the Tupinambá meant that a previously free territory, where the Indians were able to reproduce their own way of life, began to suffer limits imposed by those who came from outside. Reflecting on the arrival of non-Indians, Ms. Maria da Glória says that they "leaned on the Indians like gameleiras". The term gameleira designates trees of different genera that sprout under the cover of other trees and end up enveloping and suffocating them. The image very clearly refers to non-Indians who moved the physical boundaries of their farms, altering the land partitions and swallowing, little by little, portions of the Indians' lands. The change in the boundaries occurred in the dead of night or openly, accompanied by verbal threats or the presence of henchmen.

As the advance of the agricultural frontier in southern Bahia intensified from the late nineteenth century onward - driven mainly by cocoa monoculture, but also by tourism -, land ownership concentrated acutely, reducing the buraras (cocoa smallholdings) and increasing the conjuntos (continuous or discontinuous farming agglomerates under the same alleged owner). With the establishment of farms came numerous prohibitions for the Indians: using certain paths, hunting inside particular areas, accessing portions of forest to collect vegetal products, fishing in specific stretches of river and visiting places of memory and of religious relevance.

In this scenario, the State acted to facilitate the appropriation of lands for capitalist ends. In 1897, Bahia published State Law no. 198, which allowed for untitled holdings and lands of extinct Indian villages to be sold by the state or titled, upon payment of derisory amounts. Between 1898 and 1930, southern Bahia

11 The testimony of Ms. Maria da Glória can be seen in the short documentary “Tupinambá - The Return of the Land” (2015). Available with English subtitles at: 〈https://vimeo.com/127657520〉. 
concentrated more than $68 \%$ of the processes of the alienation of state public land, i.e. handing over public lands to individuals (Falcon 2010 [1995]: 38). The procedures for legitimising tenure were complex and timeconsuming, and the majority of the Indians were not informed about them and did not have the financial means to afford them. Thus land titling was not used to guarantee rights, rather to exercise violence. In Serra do Padeiro, such processes occurred throughout the twentieth century, transferring free lands to the hands of non-Indians.

In this context, one figure became central: the caxixeiro, i.e. someone frequently involved in caxixes. Caxixe is a regional term meaning fraud, cheating or, more specifically, shady land deals associated with cocoa. In a statement, Raymundo Pacheco Sá Barreto, who worked as a notary in Ilhéus, commented that the practice was very common: "the caxixe is a little monkey that gnaws the cocoa from the inside, you pass the field, the cocoa looks fine, you cut it down, there's nothing there, so caxixe is business that looks completely legal, but it's not" (Freitas \& Freitas 2001: 52-53). Farmers frequently falsified titles, with the connivance of notaries, or cheated in the compulsory measurement of land, performed by regional land delegates responsible for the State Land Measuring Districts, established in 1897. In other cases, the Indians were sought out by the farmers' lawyers, either personally or through correspondence, and summoned to leave their lands.

Other transactions worth highlighting include exchanges of land for insignificant amounts of money or for valuables far inferior to the land value - a bottle of cachaça, a maimed working animal, a radio, a house whose walls collapsed shortly after the deal closed, another which flooded when it rained, a cut of cloth ... In other cases, the land was delivered to non-Indians because of debts acquired by the Indians. At the time, as there was practically no banking system in the region, it was common for rural producers and merchants to extend loans for planting fields, the transportation of goods, medical expenses and funerals, among other purposes, using the land as collateral and relying on the collusion of the judicial system to then execute the mortgages in ways that were most favourable to them.

The penetration of non-Indians in Serra do Padeiro associated with the development of cocoa agriculture gained new momentum from the 1920s onwards, with the establishment of local political leaders. The name most often cited, from the coast to the mountains, is Manoel Pereira de Almeida. Born in 1880 in São Felix, in the Recôncavo Baiano region, Almeida graduated as an agronomist in Salvador in 1904. After working as a surveyor in the Land Office of Canavieiras, he approached João David Fuchs, a farmer of German origin who, between 1890 and 1900, was steward of the town of Una. Almeida married Adalice Fuchs, daughter of João David and, following the death of his first wife, married her sister, Alice. Like his father-in-law, he also led the administration of Una between 1919 and 1937, except for a brief interval due to the Revolution of 1930. Almeida maintained political influence in the municipality until the 196os. In addition, in his time, he was the largest rural property owner in Una ${ }^{12}$.

The official history extols Almeida as a "pioneer". The older Indians, however, remember him as the big boss or owner of Una. Many remember that their ancestors had to travel miles to the headquarters of Una to pay taxes; otherwise they would lose their land. As administrator, Almeida was also associated with the execution of mandatory land measurements. In the remarks of the Indians, the colonels appear as brutal figures, associated with diabolical pacts and visions. Using the occult arts, Almeida is said to have caused a bridge to construct itself; two natives described the dreadful image, transmitted to them by their ancestors, of cranes moving at night with no human help. In addition, his opulent mansion - still standing on a promontory on the bank of the Una River - is regarded as haunted.

12 Silva (2004) is the main source on which I based the brief reconstitution of Almeida's trajectory presented here, complemented by elements from Santos (2007). 
As synthesised here, based on oral reports and documentary sources, non-Indians who penetrated Tupinambá territory from the end of the nineteenth century constructed their areas favoured by the State and with the use of various forms of violence against the Indians. It is important to note that the expropriatory mechanisms set in motion by cocoa colonels and other figures of power have been updated in the contemporary practices of individuals mobilised against the recognition of Tupinambá territorial rights. Contrary to what the opponents of the Indians claim, their arrival in the disputed areas is quite recent, compared with the long Tupinambá presence in the region. Transmitting the memories of their ancestors, from generation to generation, the Indians remained in the territory despite expropriation, stuck like mourões (heavy fencing stakes), resisting and yearning for the future return of the land, which began to take form in 2004 with the first reclamations, and intensified almost a decade later.

Every year, on January $19^{\text {th }}$ and $20^{\text {th }}$, the Tupinambá of Serra do Padeiro hold the most important event of their political-religious calendar: the feast of St. Sebastian. During this time, many encantados are manifested through incorporations, announce what is to come in the year that has just begun and give advice on what indigenous strategies should be. In 2013, the encantados had an important message: it was time to speed up the reclamation, covering the entire or almost the entire village. If before, as I have argued elsewhere (Alarcon 2013), the reclamation actions had been tracing a kind of ring around the rock formation that gives the village its name and is considered the home of the encantados, now it was a question of occupying all the areas in the possession of non-Indians within the territory, except for those in the hands of non-Indians considered small or weak, i.e. poor.

The demand of the encantados, promptly received by the village, triggered numerous actions of reclamation, taking the Tupinambá strategy to an unprecedented scale - including the reclamation of some of the more extensive farms within the village. From May 2004 to May 2013, the indigenous people of this village made 22 land reclamations. Between June and December 2013, an interval of only six months, 50 new areas were reclaimed. Subsequently, other farms would also be recovered, reaching a total of 89 reclamations. The intensification of the process triggered a particularly gruelling offensive by individuals and groups opposed to demarcation, with serious repercussions for the Tupinambá. In August 2013, a vehicle carrying students from the Tupinambá Indian State School in Serra do Padeiro (CEITSP) was shot at, dozens of houses belonging to village members were burned down, Indians were beaten and robbed, vehicles belonging to government agencies identified with indigenous rights were burned, and public buildings were plundered and looted, among other attacks. In the context of the conflict, many Indians were killed in circumstances that have never been properly clarified ${ }^{13}$. These onslaughts were also accompanied by the mobilisation of the State apparatus of repression, at a level that was unprecedented in the Tupinambá case, culminating in the militarisation of the indigenous territory, which extended up to $2015^{14}$. Although the forces of repression were moved into the region with the alleged objective of curbing the conflict between the Indians and the non-Indians against demarcation, their presence did not prevent violence against the former, and there were reports that agents of the State committed violations.

The year 2013 can be considered a landmark both in terms of transformations in the context of land ownership in Serra do Padeiro and the process of indigenous mobilisation itself. Although the Tupinambá of this village continued to act in accordance with the guidelines collectively constructed from the beginning of the process of territorial reclamation, certain inflections in the way reclamation actions were

13 For further details on these and other episodes of violence against the Tupinambá, see Alarcon (2014).

14 By determination of the then Minister of Justice, José Eduardo Cardozo, on August $20^{\text {th }} 2013$, agents of the National Public Security Force (FNSP) were installed in the vicinity of the indigenous territory. In January 2014, three police bases were implanted inside the same. In February, around 5oo soldiers travelled to the region, under the command of then President Dilma Rousseff (PT), in an operation to "guarantee law and order", Operation Ilhéus. Although the Army left the area in July 2014, the presence of the FNSP was extended successively, at the request of Jacques Wagner (PT), then Governor of Bahia. The last extension order was dated November 2014 and secured the agents in the area for 90 days. See Alarcon (2017). 
conducted can be observed in the territorial distribution of the Indians, more broadly in the organisation of the village, and in the dynamics of the return of relatives. If, on the one hand, such transformations are related to tactical decisions and the greater availability of land, due to the intensification of the reclamation process, on the other, they respond to collective yearnings based on the way the Tupinambá understand their history, going back to the old lineages, each with a specific territorial domain, and how they conceive their collective project. If it is a matter of considering the reclamation process as constitutive of the village, as is argued here, it is essential to move forward within a description that at least seeks to grasp the complexities involved and to regard reclamation as a constantly changing process.

To refer to the changes in the reclamation process, some of my interlocutors resorted to the contrast between living entangled and living dispersed. The first image refers to the period prior to 2013, when reclaimed farms each housed a larger number of residents, often bringing together members of different extended families. The second refers to the present day, characterised by the reduction in the number of people per reclaimed area and by the allocation of members of different extended families in the same area only in exceptional cases. In this scenario, significant effort has been made to place each family lineage in its own domain, that is, in places identified as being occupied by their ancestors.

Broadly speaking, three levels of organisation have been constituted: the reclaimed farm, generally related to one or more nuclear families belonging to the same extended family; the sector, generally consisting of contiguous reclamations, associated with the domain of a family lineage; and the village, composed of the entirety of reclamations and smallholdings, together with relatives who, despite living outside the territory, are considered part of the village. The decision to situate each family lineage in its respective domain is conjugated with the search for balance between the concrete needs of each family (considering the number of members and their working conditions) and the characteristics of the farms (size, location, the presence and condition of permanent crops and other resources, such as houses, cocoa seed trays and cocoa driers).

However, the actual territorial distribution is not the result of the strict application of these guidelines, since circumstantial factors also apply. For example, the need to allocate families that lack a clear lineage or families whose old lineages trace back to other villages mean that, in practice, no reclamation sector is inhabited solely by members of the same lineage. Affinities or enmities, and the existence of relationships between certain Indians and specific portions of the territory other than the relationships associated with lineage are factors that, among others, assist in determining the territorial distribution. In addition, some situations lead to temporary arrangements - it is common, for example, that some people move from their homes, due to pregnancy, puerperium, illness and fechamento de trabalho [closing the body] with the pajét, temporarily changing the territorial distribution in the village. Although marked by permanence, the territorial distribution shows constant transformation.

The existence of a variety of family arrangements disperses close relatives in different reclamations (e.g. in the case of a child raised by the grandmother, whose parents live in another area), engendering an intricate network in which each person is often implicated in several places. Specific work arrangements can also lead a person to live in one reclaimed area, work on a perennial crop in another, and maintain short cycle crops in a third. This network means families can access different possibilities and resources.

In Alarcon (2013), I described the distinctions between the domains of the smallholding and the reclamation. The former, strongly identified with a nuclear or extended family, was characterised by a preponderance of the authority of the head of the smallholding or head of the family, where some rules established for the whole village did not apply. If, for example, members of a nuclear family converted to

15 A process that can last for months or years, during which a series of taboos prevail; it concludes with a ritual of closing the body in the casa do santo, the main religious space of the village where the pajé conducts the most frequented ceremonies, located at the foot of the Serra do Padeiro. 
an evangelical denomination and then refused to participate in the toré16, they could be banished from a reclamation, but never from their smallholding. On the other hand, in the reclamations - in some sense, much more directly associated with the struggle -, the power of the heads of families tended to be more nuanced by the power arising from the instances of village mobilisation. For example, a young Indian who did not get along with his nuclear family and was not welcomed by other members of the extended family, could encounter the possibility of insertion in the reclamations. Today, with the way things are heading in the identification between reclamation and nuclear or extended family, it seems that the differences between smallholding and reclamation are diminishing.

It should be noted that a series of tensions emerges in the day-to-day life between individual or family arrangements and the determinations of the collective village project, the latter, expressed in the maxim enunciated by some leaders: "It is not we who organise the land, it is the land that organises us". The expected stance of a village member engaged in the struggle is that they are ready to move from one reclamation to another, depending on security or specific strategies, among other issues. However, people initiate negotiations on a daily basis to remain in the places they have become attached to, after years of care, or to move to the areas where they believe they have the right to be. Such managements may be more or less successful, depending on factors like the prestige of each family and the relationships maintained with figures of power, including the reclamation coordinators, old lineages, the pajé and the cacique.

It is important to emphasise that relatives who fight together also disagree. The fact that the village is intersected by ties of kinship and solidarity - including, emphatically representing itself as a united and organised village - in no way means the absence of envy, gossip, witchcraft. In this sense, it is fundamental to discuss the possibility of village construction through the handling of divergences between relatives, considering the relationships between the different family lineages, including the depictions that the members of one make of the others. These relationships are quite complex - opposing either whole lineages, or parts of different lineages or the same - and they change over time. In addition, they are developed in connection with collective efforts to ensure some balance between lineages in the administration of village life, including their representation in the Association of Tupinambá Indians of Serra do Padeiro (AITSP), at the CEITSP and in other areas. It is also important to look at indigenous representations of returning relatives after living on farms or in towns, and at the relationships established between them and those who already live in the village - some returns are deeply disturbing. Thus, it seems to me important to reflect on the role of divergence, whether or not it is visible, in collective actions.

Juxtaposing living entangled and living dispersed, the Tupinambá identify advantages and disadvantages in each situation. On the one hand, they emphasise that the new arrangement tends to contribute to a reduction in fights between neighbours and an increase in family income, since each now has more farmland available. On the other hand, some Indians argue that the new configuration can loosen ties, including weakening the village in the face of enemies. It is important to note, however, that the construction of roads and the greater availability of motorcycles, in particular, but of other vehicles as well, has created a scenario of intense movement, in which these modes of transit are added to dislocations on foot, in some cases, replacing the latter. Thus, perhaps, the discourse on the loosening of ties speaks more of concern and caution, than of an effective reduction in encounters. In any case, statements on the importance of visiting relatives intensified, thus a clear effort was made to reinforce the existing meeting spaces, to create new ones and to maintain the ceaseless sharing of care, knowledge and resources that serves to connect the village.

16 The toré is a central political-religious ritual for Indians of the Brazilian Northeast. See Grünewald (2005). 
In concluding this section, it should be noted that the issues listed here, among others that are related to the territorial distribution in the village, have direct implications on the dynamics of the return of relatives. Previously, returning Indians were usually allocated to reclamations already occupied by other families - sometimes they had to build houses of mud or wooden boards, or erect canvas shacks. Today, it is common for new returnees to become the first occupants of a recent reclamation - in some cases, actually carried out to receive them. A returned family could also temporarily settle with relatives, until they carry out a reclamation themselves. I regard analysis of these different forms of entry into the village to be fundamental. Likewise, it is important to consider that, in a sense, each Indian or group of Indians that returns finds a different village from that of their relatives who have come in previous waves, such that each return also triggers new transformations.

\section{Relatives unite in the struggle, the struggle unites (and disunites) relatives}

There was a time when the Tupinambá were scattered. A time of giving birth on farms, of having no ground to bury the stump of the umbilical cord of your children ${ }^{17}$, of placing your belongings on your back and leaving for the city. Those who managed to stay on their smallholdings were increasingly squeezed by non-Indians. My interlocutors used to allude to the fact that, when recalling their oldest memories of childhood, they found themselves on a different farm than the one where they had been born. Take the example of a 30-year-old teacher who, from the age of nine to sixteen years old, lived on nine different farms, four of which have now been reclaimed. As you can surmise, she lived on roughly one farm per year. Reconstructing their trajectories, many Tupinambá Indians situate their exit from the village at a time when the struggle had not begun, when living conditions were scarce, and they were being driven out by farmers.

Elsewhere (Alarcon 2013), I sought to discuss how the martyrdom of the ancestors and the trauma of dispersion, transmitted from generation to generation, were triggered in the framework of the land reclamation process. The article deals with situations that were often only alluded to or confided by some and silenced by others, regarding, for example, Indians who became prostitutes, those who had to give their children to others to raise, the many relatives who are understood to have gone mad ${ }^{18}$ and those who disappeared. Much of the political power of the return of relatives comes from remembrance of the dispersion - understood within the framework of territorial expropriation and invested with suffering -, both by those who left and by those who saw relatives leave or heard the stories about the departures of ancestors.

The struggle for land thus draws on narratives concerning other struggles, woven into spheres that are occasionally more obscure and often occur outside the territory, conforming to a worldview that affirms that when you are poor, to live is to fight ${ }^{19}$. At the same time, however, leaving the village entails

\footnotetext{
17 "In rural areas, the custom is for mothers to bury their newborn baby's umbilical cord so that they stay emotionally attached to them and to their homeland. Since migration in search of better job opportunities in such regions is common, such a magical act (a 'charm') increases the chances that the child will one day return to their native land" (Pacheco de Oliveira 1998: 64).

18 For the Tupinambá of Serra do Padeiro, madness is closely connected with religiosity, particularly to the relationship with the encantados. When puberty arrives, it is common to go through a period of madness, marked by visions - including those expressed in prophecies related to the struggle for land -, which tends to end with the ritual of closing the body with the pajé. Within the framework of dispersion, madness can express a form of agency of the encantados, demanding that the Indian in question returns to the territory, to re-establish or reinforce their kinship ties, resume their religious obligations and engage in the struggle.

19 It is worth highlighting the interesting discussion by Comerford (1999) concerning the meanings of the term struggle, mainly considering data obtained in western Bahia. In this and other contexts, the word is used to characterise both the daily lives of the poor and the clashes between peasants and landlords, and, more restrictively, to refer to the field of trade unions. In the first case, which is intimately related to suffering, struggle alludes to daily living "that is permanently restored as a critical situation" (Comerford 1999: 26). In this sense, the notion is also used to qualify "the daily experience of people who have been struck very unfavourably by processes of rural transformation and have begun living precariously as temporary employees, sharecroppers in very unstable situation, or who have had a difficult migration experience", a situation often aggravated by personal dramas and climatic events, such as drought (Ibid).
} 
dimensions of discovery and learning, affording an opportunity to acquire skills (obtaining songs and prayers from others places, learning to read, to perform manual crafts, to use playing cards for divination...) and to gather stories that, within the process of village construction, add to the framework of narratives shared by the Tupinambá. Thus, reflecting on the political strategies of the Tupinambá of Serra do Padeiro necessarily inquires into a period when there was a marked tendency to leave the village.

With this in mind, during the census I conducted in 2016, I sought to gather quantitative and qualitative data on the trajectories of the Indians who lived in Serra do Padeiro at that time. We elaborated genealogies and discussed, among other issues, the displacements undergone by the Indians throughout their lives, considering the transformations in their situations in relation to housing, land tenure and work. It is important to note that the indigenous perspective on the experience of expropriation also unfolds in less obvious aspects, such as recurrent complaints concerning the temporality of the city and the feeling of isolation and confinement, affirmations on the discrimination that occurs there and that everything is different. Moreover, according to my interlocutors, in the city, it is common for others (non-relatives) to practice witchcraft against them, leading to illness or death.

Among the testimonies obtained during the census, it was possible to identify a set of recurrent destinations for Indians who left the village - dispersing to distant locations, in the south and central-south of the country, and even to the Amazon region -, associated with networks of relationships established outside the village. Some comments accentuated the precarious living conditions in these places: some have lived in favelas, there were hodmen who slept in the building itself (i.e. inside the skeleton of the building under construction, not in accommodation), an Indian who felled trees in the Amazon rainforest and whose only shelter was a precarious shack in the forest, and others who lived in farmhouses or under a tarp in landless encampments. The list of predominant occupations and labour situations in the dispersion, and the comments associated with them, provide an idea of what the imperative of working for others means for Tupinambá Indians. In reference to the city, the complaints tended to revolve around the cost of living, while in relation to farm work, depending on the employer, they mentioned impediments to working their own plots of land, eating fruits from the tree, and relatives visiting their home, among other prohibitions.

In the same census, I tried to gather information about relatives (grandparents, parents, siblings, children and grandchildren) who were outside the village, considering the anticipation and expectations of the interviewees about the possibility of their return. For the Tupinambá of Serra do Padeiro, living in the village and being part of the village are not synonymous. The number of people who make up the village as conceived by the Indians themselves includes relatives who live elsewhere but are closely linked to the life of the group, as well as relatives who are understood to be somewhere else but will return. Therefore, it is essential to look at the meanings of being inside and outside the village, according to the Tupinambá perspective, contrasting geographical limits with the limits demarcated by participation in the movement for territorial recovery. A significant tendency to maintain ties between relatives and with the territory is evident, even when outside the village. Among my interlocutors, emphasising the difference between leaving the village and abandoning the village is a common expedient ${ }^{20}$. Attention to this fact is fundamental when it comes to characterising the political subject delineated in the reclamation process. Contemporaneously, conceiving of the return of relatives traverses understanding how many of them remained part of the village despite the dispersion, and how this has been sustained over generations.

\footnotetext{
20 Arruti's reflections on Pankararu mobility, which initiated a significant afflux from Pernambuco to São Paulo in the 1940s, are evocative. With this in mind, the author considers territory to be "a place of reference that you can always return to as a way of constantly reproducing indigenous identity" (Arruti 1996: 9o). For him, “territory essentially appears as a reference, fundamental, but not like a mould, opening up to the 'vast exterior' of Pankararu identity" (Ibid: 190).
} 
It is possible to identify repeated efforts on the part of those who leave the village that their destinations are located, whenever possible, in the vicinity or even within the indigenous territory itself, even while on farms, thus guaranteeing proximity with their relatives and place of origin. There are several cases where neighbouring towns were preferred to more distant locations, where they bought smallholdings nearby or began living in landless encampments or agrarian reform settlements in the region. Some of these situations involved daily dislocations between the house (in town) and the smallholding (in the village), with more complex arrangements involving circulation among more than one farm and more than one house.

Even travelling to more distant destinations usually does not cause loss of communication with the village. In the field, I was able to observe how mothers and grandmothers continue to care for their relatives at a distance, sending and receiving photographs, teaching remedies over the telephone (and now through social networks) or requesting prayers from the pajé. There is also an intense flow of goods and money, in the form of orders, presents, pensions and assistance. Visits to the village - which commonly extend throughout the holiday period, although they may be delayed due to financial difficulties - can be understood in this context as privileged situations for reinforcing ties, which serve as nourishment during periods of distance. The same can be said, for example, of relatives who return to tend pregnant and puerperal women.

Beyond the everyday devices for maintaining bonds, the comments made by the Tupinambá indicate an even greater depth of ties with relatives and territory. For example, the descendants of one of the old lineages of the village, João Ferreira da Silva (c. 1905-1981), known as João de Nô, narrated that he could talk to a brother who was in Rio de Janeiro without needing a telephone. Even if his case is special, because he is someone recognised for his powerful prayers, the understanding that it is possible to connect with the bodies and minds of distant relatives (through prayers and other forms), to move during sleep and to communicate in dreams is widespread ${ }^{21}$. An indigenous woman who spent two and a half months imprisoned with her baby, due to the struggle for land, said that the mastitis she developed in prison, aggravated by the negligence of the officials, only improved after her mother, who was in the village, squeezed her breasts while they both slept, leading her to wake up covered with secretion. Even if the ties are weakened, they seem to persist to the point of sensing that a separated relative is about to die, even when nothing can be done to prevent it.

The persistence of the place in the form of remembrance or, in the case of those who were born outside the village, in the form of images created by relatives, should also be highlighted. I have collected a rich set of narratives told to me by an indigenous woman born in the sertão of Pernambuco, as a consequence of a long series of wanderings undertaken by her family, in which she describes what the village was like in her father's childhood, a man born and raised in Tupinambá territory. It is important to add that she first stepped onto this land as an adult woman, married, and the mother of three children. The richness of detail present in the narratives and the ambience they are able to capture led me to think about the way in which the relationships of this woman and her siblings with the territory were being constructed outside of it, through the words of their father, and were updated later, when they engaged in the reclamation movement.

Thus, in the process of territorial recovery conducted by the Tupinambá of Serra do Padeiro, a collective of political action is also defined to some extent by people outside the village, some of whom are unaware that they form part of it. It is possible to discern distinct forms of actuation in the struggle for land engaged in by Indians living in the city - for example, by providing lodging for relatives who are

21 In research conducted with the Pataxó Hã-Hã-Hãe, also in southern Bahia, Pedreira (2016) reflects on the problem of distance in relationships considering devices like dreams, night travels and visions, which even connect the living and the dead - and looks at narratives of expropriation and return to the Caramuru Catarina-Paraguassu Indigenous Reserve. 
travelling to claim certain rights or by providing them with information on the actions and plans of groups against demarcation in neighbouring towns. That an Indian who resides outside the village expresses the desire to return may lead relatives to undertake actions to create the conditions to accelerate their return. Furthermore, reclamations have been conducted with a view to the return of absent relatives who have not even signalled their intention to come back. Therefore, it is important to also consider the indirect agency of Indians who reside outside the village in the process of territorial recovery.

Even when you only consider the Indians who are physically in the village at a given moment, it is clear that the project of the Tupinambá of Serra do Padeiro allows for different modes of participation. Representing the village as homogenously engaged is a misconception. Indeed, we are faced with an interesting balance in motion, one not free of tensions with regard to the forms of participation of each person or family - which may even vary over time, and is often associated with the relationship dynamics between family lineages. Thus, a question that could be viewed as simple (what does it mean to participate in the village?) encounters a variety of responses, among the Indians, that refer both to the way each narrates their involvement, based on certain frames of reference, and on the extent of their participation. Actuating in reclamation actions, living on reclaimed farms, participating in community smallholdings, engaging in work that contributes income to the movement, participating in AITSP meetings, contributing financially to the same, participating in trips to claim indigenous rights are a few of the stated replies, and within the interstices lie the concrete commitments.

Even though the reclamations are what they are - founding aspects of the village in its contemporary existence - not everyone who is part of Serra do Padeiro is involved in them. Some say that their temperament is not suited to this; others that their health will not allow them to; still others offer no justifications, stating only that the moment they entered the struggle, they made it clear that it would be on their terms. Even among those involved in the reclamations, the forms of participation are diverse, ranging from those who take part in entering the farms, and those who live in these areas, to those who provide reinforcement to the residents in the form of visits or short stays, days after the inaugural action or when there is the threat of land repossession. Nor should we forget those who participate from afar, praying for a good outcome.

On a more general level, as a relative, the only requirement to be part of the village is to not act badly - a formulation which, as you can see, has conveniently undefined contours. Many private and public remarks affirm that the village should allow for different ways of living - which fit within certain goals, i.e. they conform to collectively established agreements - which must include different forms of participation in the struggle. Nevertheless, within the framework of relationships between families, the involvement of others in the struggle is subject to daily scrutiny and comparison with an individual's own engagement, which they have the opportunity to exalt before the village in any number of situations where the Indians devote themselves to remembering their bravery and recounting their deeds. In this context, and considering that the Tupinambá of Serra do Padeiro have managed to remain in possession of all the areas recovered while moving forward with their main strategy, it seems important to reflect on the role of divergence, whether or not it is visible, in collective actions ${ }^{22}$.

To a greater or lesser extent, returning relatives can be found in practically all of the extended families in the village. Although there are numerous cases of Indians who seek out the village to express their desire to join the territorial recovery movement - which often materialises in a conversation with the cacique, or in a request that a relative who resides in the village do so on their behalf -, in the majority of descriptions,

22 Analysing the "ritual" and "everyday" actions of peasant movements and organisations, Comerford (1999) draws attention to the presence of concepts that are more or less divergent and different forms of participation in the same, such that these discontinuities are constitutive of the very processes of struggle. 
the driving force is the call of relatives or of one relative in particular. Even a return that is not triggered by a concrete call should be understood, in a broader sense, as the result of the deep convocation that is the call of blood, allied with the actuation of the encantados.

Enabling the return of relatives means ensuring the material conditions for that to occur and be sustainable. Although the recovery of areas is the first condition for their return, other factors are also involved. Relatives who have recently arrived frequently need help until they stabilise - it is common for the AITSP to provide building materials, when necessary, and even basic food supplies, until it is possible to them to sustain themselves working in the fields or get a job in the village. Having an association with cash on hand and a reputation to buy on credit from local merchants, if necessary, is a condition that facilitates their return. Similarly, it is important to note that the existence of jobs contributes to establishing people in the village, while offering alternatives for those who do are unable or who lack the inclination to work in the fields.

In addition, the offer of school up to the completion of secondary education, including technical training, works to attract Indians and maintain them in the village, while reversing a historical tendency: leaving to study. That the village can offer health care, that the movement has been able to ensure, with certain difficulties, that the village was included in the federal rural electrification program, that when necessary, the AITSP mediates the relationships between the Indians and the State (for example, guaranteeing access to social security) are all mobilisation factors. Thus, the advancement of the movement in obtaining rights - which led to the allocation of resources by the State to operate the school, to install a small community health care clinic and dental service, and to hire Indians to work in the areas of education, sanitation and health care - also affects the process of the return of relatives.

In making these considerations, it is never my intention to suggest that involvement in the process of territorial recovery can be reduced to calculations of personal benefits, while blurring its profound implications and causalities, as some of its opponents argue. The point is to indicate that engagement does not necessarily result from full and a priori comprehension of indigenous rights and of the political project in course in the village - evidently, because the project of village construction is ongoing. Engagement seems to have much more to do with having expectations of and some confidence in the possibility of building a way of life among relatives, in association with the potential of the project itself, which can provide forms of involvement within the same that did not necessarily exist from the outset.

In some families, the data on returns is striking; here, I consider one of the extended families living in the village as an example. Three generations were heavily impacted by expropriation, their members wandered between farms, worked in domestic cleaning services, and even in situations analogous to slavery. In 2004, before the onset of the reclamation process, 12 Indians from this family were incorporated into the village, 15 people including spouses. All of them lived clustered around one female relative who had settled some land. Today, 72 extended family members live in the village. The reclamation process attracted 39 people, and the reunited family tripled in size. Since then, there have been 18 births. Today, the family is spread over five reclaimed farms and one smallholding. Clearly, the availability of land not only allowed for the return of a significant number of relatives, but has ensured that the family growth, through marriages and births, no longer implies renewed dispersion due to the lack of means of support. 
In the past few years, some nuclear families who had apparently consolidated their permanence in the city returned, strongly undermining the assertion of "trajectories of no return", even among Indians who have lived outside the village for decades ${ }^{23}$. This is the case of an Indian who moved to the metropolitan area of São Paulo at the age of 18, looking for a job, after his family saw their land dwindle drastically. In the city, he got a job in a factory. He married a co-worker, also from the Northeast, bought a house, had a daughter, and convinced two of his brothers to work in the same factory and live nearby, accompanied by their respective nuclear families. After living eighteen years outside Serra do Padeiro, in 2008, four years after the territorial recovery process began, he came back to live in the village. He returned to working in the fields and his wife opened a small confectionery shop. Today, he coordinates the work in the fields of his extended family. Besides being a connoisseur of the woods that surround the rock formation that gives the village its name, he holds detailed information regarding the historical process of occupying the foot of the mountain range.

The two cases I mention above contrast in different ways, for example, regarding the socioeconomic conditions of the Indians before they joined the process of territorial recovery. Both, however, seem to me indicative of the possibilities of the change in directions that open up during the reclamation process, engaging dispersed relatives in a collective project based on what is said to be the ideal of every couple (staying close to their children and grandchildren) and, more broadly, the ideal of the group (having land to reunite all the relatives). The recent, expressive increase in areas of land among the Indians, mentioned in the previous section, has enabled the intensification of the process of the return of relatives; at the same time, the ability to mobilise such relatives seems to be a fundamental condition for the development of the collective project of the Tupinambá of Serra do Padeiro.

In Serra do Padeiro, if relatives unite in the struggle, the struggle also unites relatives. We are faced with a kind of political action that is guided by kinship ${ }^{24}$, understood by the Indians as a bond that, even as it retraces the past back to the old lineages, when latent, it can be activated and updated within the framework of the process of territorial recovery itself. The examples are numerous; I will mention only two. Married to an overseer on a farm, an Indian woman only met most of her relatives as an adult, when the area in question was reclaimed. Even though she lived a short distance from her uncles, aunts and cousins, the routine of life on the farm isolated her from this circle, especially after the first reclamation took place - the alleged owners of the farm, knowing she was indigenous, began to watch the movements of her nuclear family closely. Another interlocutor, who became an orphan as a young woman, described in a choked voice the moment when she learned that she had relatives, within the context of the reclamations.

23 In research dedicated to the Brejo and Agreste Paraibanos, Garcia Jr. (1989) already highlighted that the displacement of peasants to urban areas, as part of the expansion of cattle and sugar cane lands, did not necessarily imply their "proletarianisation". In the trajectories analysed by the author, the journey to the city also composed the possibility of returning to the countryside and the "progressive breakdown of the subjection in the North", with the eventual acquisition of your own land (Ibid: 269). Therefore, insertion in the industrial labour market was not a path with no return, but a path that could lead, among other places, to fields and peasant production. "The hypothesis of one way emigration is therefore arbitrary, since a priori it rules out any study of displacements that do not necessarily end in 'abandoning declining areas' and 'integrating into the poles of prosperity"' (Ibid: 13).

24 In my efforts to construct an analytical strategy to understand living and struggling among relatives, I have established dialogues with authors like Comerford (2003), particularly considering his reflections on the processes of familiarisation and defamiliarisation, which are traversed by everyday conflict and define territories of kinship; Franco (2001), who while investigating the connections between family and political mobilisation, proposed the notion of political coalescence of relatives, arguing that affectivity supports collective action, solidarity between relatives and the willingness to take risks for each other, in a framework of conflict; Ayoub (2016), who while focusing on fights between neighbours and relatives, reflects on knowing how to live or knowing how to live together; Silva (2015), who discusses the constitution of borders within populations that are understood as collective, united by kinship ties, considering the constitution of identity by contrast and, simultaneously, by proximity, and examines the elasticity of the terms family and relative, whose meanings are necessarily contextual; Antunes (2016), who investigates the daily exercise of marking differences between the inhabitants of the same ethnic territory; Pedreira (2016), who while researching the Pataxó Hã-Hã-Hãe, in an ethnographic context that maintains numerous connections with that of Serra do Padeiro, explores the issue of difference, considering the constant movement of becoming relatives for people and families with different origins; and Benites (2014), whose analysis of the reoccupation processes of tekoha engaged in by the Guarani and Kaiowa, shows extended families occupy a central position. 
I understand, however, that the claim that the struggle unites relatives has even greater scope: the process of territorial recovery has extended the meaning of kinship. If previously, the explanatory emphasis of kinship was on blood, with each person attributed to an old lineage, whether or not each nexus that united them was known, it now seems possible to consider another definition of relative: those with whom you fight together. The deep bonds that are established between those who engage in direct action side by side require attention. When I asked one of my interlocutors, while trying to place him within the genealogical diagrams, who his close relatives were, he replied emphatically: "everyone in the village". Upon reformulating the question, he promptly indicated who his parents, siblings, uncles, aunts and grandparents were. But turning again to the issue of "close relatives", he was inflexible. My belief is that if we take his statement at face value, it is precisely this sense of kinship that he is talking about.

On the other hand, we must consider that struggle also disunites relatives. The same process can lead to the weakening or rupture of ties with relatives who are against the mobilisation, aligned with the perspective against demarcation ${ }^{25}$. It can get to the point where, according to reports, an engaged Indian was threatened with death by a brother who was opposed to participating in reclamation actions. Even when it does not involve ruptures, estrangement between relatives caused by the land conflict, even when not intentional, should be taken into account. Some Indians, the elderly and sick among them, left the village following onslaughts by state forces of repression, due to the spectre of new attacks. Fearing further violence, some Indians who live outside the village stopped visiting their children. In at least one case, an Indian moved from Serra do Padeiro after being beaten and having his belongings stolen in the nearby town, as a reprisal for the Tupinambá mobilisation. In any event, for those who remain, the adversities are also interpreted positively, since they unite relatives, provide perspective to those who engage in the collective project and teach them to fight.

\section{Final considerations}

The research that I have been developing dialogues with reflections engaged in different Latin American contexts, principally around notions of living well, with the intention of contributing to analysis of the processes of creating indigenous utopias. In reflecting on the practices and representations put forward in these processes, I seek to collaborate with certain keys to interpreting the dynamics of mobilisation among indigenous peoples, considering the political concepts and categories created by struggle itself. It should be borne in mind that the perspectives of the Tupinambá of Serra do Padeiro are not restricted to the village, rather in their project they conceive of the possibility of subverting power relations in the region, making connections with other struggles, such as those of Brazil's landless movement and the quilombolas, to mention two examples.

In this article, I emphasise the need to invest in approaches to indigenous mobilisation processes that bear in mind their dynamic character, considering, in the case of the Tupinambá of Serra do Padeiro, that the strategies of territorial recovery and the existing arrangements in the village are transformed daily within the framework of the struggle itself, informed by both deeper and circumstantial reasons. I also highlight that the development of a collective project should not presume a homogeneity of perspectives and forms of participation, nor the absence of conflict between those engaged in the same.

25 The notions of familiarisation and defamiliarisation, as elaborated by Comerford (2003), may be useful here. According to the author, in the framework of processes of familiarisation and defamiliarisation, traversed by everyday conflict, territories of kinship are delimited, forming a "field of relations that in principal are of trust, mutual aid, respect, tolerance, intimacy, as well as, to varying degrees, sharing characteristics and responsibilities", but that also imply hierarchisations, ruptures and segmentations (Ibid: 34 ). 
Further, I argue that the interpretation of the territorial recovery process should confer centrality to the dispersion (within the framework of the expropriation process) and the return to the village (in the context of reclamation). Focusing on the maintenance of ties between relatives and with the territory, even in the event of leaving the village, I offer some elements to characterise the political subject formed in the reclamation process, defending that we face a political collective also composed of people who are outside the territory. The text briefly outlined some aspects that I consider important in the process of mobilisation, such as the roles of kinship and the encantados in precipitating the return of the Indians, the material implications of the return and some of the conditions required for it to be effective and sustainable. Finally, I briefly developed the argument that relatives unite in the struggle, while the struggle unites and disunites relatives, and propose a definition of relative informed by the process of territorial recovery under way in Serra do Padeiro: those with whom you fight together.

Received on October 19, 2017

Approved on December 18, 2017

Translation by: Philip Badiz 


\section{References}

ALARCON, Daniela Fernandes. 2013. O retorno da terra: as retomadas na aldeia Tupinambá da Serra do Padeiro, sul da Bahia. Dissertação de mestrado, Universidade de Brasília - Brasília.

. 2014. "Retomadas de terras e ocupação militar: a disputa pela aldeia Tupinambá de Serra do Padeiro, Bahia”. Anais 29a RBA. Brasília: Associação Brasileira de Antropologia. Mimeo.

. 2017. "Doze anos de luta pela demarcação da TI Tupinambá de Olivença". In: B. Ricardo; F. Ricardo (orgs.), Povos indígenas no Brasil: 2011-2016. São Paulo: Instituto Socioambiental. pp. 713-717.

ALMEIDA, Alfredo Wagner Berno de. 2008. Terras de quilombos, terras indígenas, "babaçuais livres", "castanhais do povo", faxinais e fundos de pastos: terras tradicionalmente ocupadas. Manaus: PGSCA-UFAM.

ANTUNES, Marta de Oliveira. 2016. A terra que volta: gerindo territórios, memórias, conflitos

e normas em Conceição das Crioulas. Tese de doutorado, Universidade Federal do Rio de Janeiro - Rio de Janeiro.

ARRUTI, José Maurício Paiva Andion. 1996. O reencantamento do mundo: trama histórica e arranjos territoriais Pankararu. Dissertação de mestrado, Universidade Federal do Rio de Janeiro - Rio de Janeiro.

AYOUB, Dibe Salua. 2016. Entre jagunços e valentes: familia, terra e violência no interior do Paraná. Tese de doutorado, Universidade Federal do Rio de Janeiro - Rio de Janeiro.

BENITES, Tonico. 2014. Rojeroky hina ha roike jevy tekohape (Rezando e lutando): o movimento histórico do Aty Guasu dos Ava Kaiowa e dos Ava Guarani pela recuperação dos seus tekoha. Tese de doutorado, Universidade Federal do Rio de Janeiro - Rio de Janeiro.

BRASIL. Instituto Brasileiro de Geografia e Estatística. 2012. O Brasil indígena: povos/etnias. Outras etnias cujas línguas não são classificadas nem em troncos nem em familias (tabela). Disponível em: <http://indigenas.ibge. gov.br/es/estudos-especiais-3/o-brasil-indigena/povos-etnias> (último acesso: 27 maio 2014).

BRASIL. Ministério da Justiça. Fundação Nacional do Índio. 2009. Relatório final circunstanciado de identificação da Terra Indígena Tupinambá de Olivença. Brasília.

BRASIL. Ministério da Saúde. Secretaria Especial de Saúde Indígena. Sistema de Informação da Atenção à Saúde Indígena. 2013. Quantitativo populacional dos indígenas cadastrados no SIASI em 2013 por diversos parâmetros de territorialidade indígena ou nacional (tabela). Disponível em: <http://portalsaude.saude. gov.br/index.php/o-ministerio/principal/secretarias/secretaria-sesai/mais-sobre-sesai/9518-destaques> (último acesso: 18 ago. 2017).

BRASIL. Ministério Público Federal. Procuradoria da República em Ilhéus. 2007. Ação civil pública com pedido de liminar contra a União e a Fundação Nacional do Índio. Processo no2007.33.01.001700-9. Ilhéus, 17 dez.

. 2013. Ação civil pública com pedido de liminar contra a União. Processo noooo3186-70.2013·4.01.3311. Ilhéus, 27 set.

BRASIL. Ministério Público Federal. Procuradoria da República na Bahia. 2012. Ação civil pública por dano moral em face da União e da Fundação Nacional do Índio. Processo no261-68.2012.4.01.3301. Ilhéus, 16 jan.

BRASIL. Presidência da República. Decreto no 1.775, de 8 de janeiro de 1996. Dispõe sobre o procedimento administrativo de demarcação das terras indígenas e dá outras providências. Brasília.

CALDEIRA, Clovis. 1954. Fazendas de cacau na Bahia. Documentário da Vida Rural, no 7. Rio de Janeiro: Ministério da Agricultura, Serviço de Informação Agrícola.

CARVALHO, Maria Rosário de; CARVALHO, Ana Magda (orgs.). 2012. Índios e caboclos: a história recontada. Salvador: EDUFBA.

CARVALHO, Maria Rosário de; REESINK, Edwin; CAVIGNAC, Julie (orgs.). 2011. Negros no mundo dos índios: imagens, reflexos, alteridades. Natal: Editora da UFRN. 
COMERFORD, John Cunha. 1999. Fazendo a luta: sociabilidade, falas e rituais na construção de organizações camponesas. Coleção Antropologia da Política, 5. Rio de Janeiro: Relume Dumará/ Núcleo de Antropologia da Política, UFRJ. . 2003. Como uma familia: sociabilidade, territórios de parentesco e sindicalismo rural. Coleção Antropologia da Política, 22. Rio de Janeiro: Relume Dumará/ Núcleo de Antropologia da Política, UFRJ.

COUTO, Patricia Navarro de Almeida. 2003. Os filhos de Jaci: ressurgimento étnico entre os Tupinambá de Olivença, Ilhéus, BA. Trabalho de conclusão de curso, Universidade Federal da Bahia - Salvador. Mimeo. . 2008. Morada dos encantados: identidade e religiosidade entre os Tupinambá da Serra do Padeiro, Buerarema, BA. Dissertação de mestrado, Universidade Federal da Bahia - Salvador.

FALCÓN, Gustavo. 2010 [1995]. Coronéis do cacau. 2a ed. rev. Salvador: Solisluna Editora.

FARIA, Camila Salles de. 2016. A luta guarani pela terra na metrópole paulistana: contradições entre a propriedade privada capitalista e a apropriação indígena. Tese de doutorado, Universidade de São Paulo - São Paulo.

FRANCO, Mariana Ciavatta Pantoja. 2001. Os Milton: cem anos de história familiar nos seringais. Tese de doutorado, Universidade Estadual de Campinas - Campinas.

FREITAS, Janete Ruiz de; FREITAS, Antonio Fernando Guerreiro de. 2001. Sá Barreto (Testemunhos para a história). Ilhéus: Editus.

GARCIA JR., Afrânio Raul. 1989. O Sul: caminho do roçado: estratégias de reprodução camponesa e transformação social. São Paulo/ Brasília: Marco Zero/ Editora Universidade de Brasília; CNPQ, MCT.

GRÜNEWALD, Rodrigo de Azeredo. 2005. Toré: regime encantado do índio do Nordeste. Recife: FUNDAJ/ Editora Massangana.

MAGALHÃES, Aline Moreira. 2010. A luta pela terra como "oração": sociogênese, trajetórias e narrativas do "movimento" Tupinambá. Dissertação de mestrado, Universidade Federal do Rio de Janeiro - Rio de Janeiro.

MONTEIRO, John Manuel. 2001. Tupis, tapuias e historiadores: estudos de história indígena e do indigenismo. Tese de livre docência, Universidade Estadual de Campinas - Campinas.

PACHECO DE OLIVEIRA, João. 1998. "Uma etnologia dos 'índios misturados'? Situação colonial, territorialização e fluxos culturais". Mana. Estudos de Antropologia Social, 4(1): 47-77.

(org.). 2004. A viagem da volta: etnicidade, política e reelaboração cultural no Nordeste indígena. Rio de Janeiro: Contra Capa.

. 2006. "Políticas indígenas contemporáneas: régimen tutelar, juegos políticos y estrategias indígenas". In: (org.), Hacia una antropología del indigenismo: estudios críticos sobre los procesos de dominación y las perspectivas políticas actuales de los indígenas en Brasil. Rio de Janeiro: Contra Capa/Centro Amazónico de Antropología y Aplicación Práctica. pp. 127-150.

. 2011. A presença indígena no Nordeste: processos de territorialização, modos de reconhecimento e regimes de memória. Rio de Janeiro: Contra Capa.

. 2016. O nascimento do Brasil e outros ensaios: "pacificação", regime tutelar e formação de alteridades. Rio de Janeiro: Contra Capa.

; MURA, Fabio; SILVA, Alexandra Barbosa da (orgs.). 2015. Laudos antropológicos em perspectiva. Brasília: ABA.

PEDREIRA, Hugo Prudente da Silva. 2016. Os Pataxó Hã hã hãe e o problema da diferença. Dissertação de mestrado, Universidade de São Paulo - São Paulo.

POLLAK, Michael. 1989. "Memória, esquecimento, silêncio". Estudos Históricos, 2(3): 3-15.

SANTOS, Milton. 1957. Zona do cacau: introdução ao estudo geográfico. $2^{\underline{a}}$ ed. rev. São Paulo: Companhia Editora Nacional. 
SANTOS, Soanne Cristina Almeida dos. 2007. Una: poder político municipal 1939-1965. Trabalho de conclusão de curso, Universidade Estadual de Santa Cruz - Ilhéus. Mimeo.

SILVA, Katiane. 2015. Parente é serpente: ambientalismo, conflitos sociais e uso de recursos naturais no AuatiParaná, Amazonas. Tese de doutorado, Universidade Federal do Rio de Janeiro - Rio de Janeiro.

SILVA, Rosilane Maciel. 2004. "O coronel Manoel Pereira de Almeida e a formação do município de Una". Cadernos do CEDOC, 3 (Poder rural): 9-44.

TÓFOLI, Ana Lúcia Farah de. 2010. As retomadas de terras na dinâmica territorial do povo indígena Tapeba: mobilização étnica e apropriação espacial. Dissertação de mestrado, Universidade Federal do Ceará Fortaleza.

VIEGAS, Susana de Matos. 2007. Terra calada: os Tupinambá na Mata Atlântica do sul da Bahia. Rio de Janeiro: Editora 7 Letras.

WOORTMANN, Ellen F. 1994. Herdeiros, parentes e compadres: colonos do sul e sitiantes do Nordeste. São Paulo/ Brasília: Hucitec/Edunb.

WOORTMANN, Klaas. 1988. “'Com parente não se neguceia': o campesinato como ordem moral”. Série Antropologia, 69: 1-108.

Daniela Fernandes Alarcon

Federal University of Rio de Janeiro, National Museum, Post-graduate Programme in Social Anthropology, Rio de Janeiro, RJ, Brazil

Contact: alarcon.df@gmail.com 